\title{
APLIKASI SCREENING OF REPRODUCTIVE HEALTH (SHE) DALAM UPAYA PENINGKATAN KESEHATAN REPRODUKSI WANITA
}

\author{
${ }^{1)}$ Azizatul Hamidiyah, ${ }^{2)}$ Muhasshanah \\ 1) Program Studi Kebidanan, Fakultas Ilmu Kesehatan, Universitas Ibrahimy \\ ${ }^{2)}$ Program Studi Teknologi Informasi, Fakultas Sains dan Teknologi, Universitas Ibrahimy \\ Sukorejo Situbondo Jawa Timur \\ E-mail : ${ }^{1)}$ azizatulhamidiyah@gmail.com, ${ }^{2)}$ muhasshanah@gmail.com
}

Kata Kunci: Kesehatan Reproduksi, Screening of Reproductive Health (SHE), Sistem Pakar.
Keywords:

Health Reproduction,

Screening of Reproductive

Health (SHE), Expert System.

\section{Info Artikel}

Tanggal dikirim: 6 Juli 2020

Tanggal direvisi: 21 Juli 2020

Tanggal diterima: 22 Juli 2020

DOI Artikel:

10.36341/jomis.v4i2.1385

Creative Commons Attribution-

NonCommercial-ShareAlike

4.0 International License.

\begin{abstract}
ABSTRAK
Anemia, keputihan, gangguan menstruasi, dismenorhea merupakan beberapah masalah kesehatan reproduksi yang dialami oleh wanita baik dari skala ringan hingga berat. Dan beberapa dapat berakibat fatal hingga kematian. Berdasarkan data WHO, gangguan ataupun masalah pada kesehatan reproduksi wanita lebih banyak dibanding masalah reproduksi laki-laki yaitu $33 \%$ dan pada laki-laki yaitu 12,3\%.Akan tetapi, masalah kesehatan reproduksi ini tidak diimbangi dengan tingkat pengetahuan oleh wanita akan masalah yang dialami. Sehingga tidak jarang, para wanita baru menyadari setelah keadaan semakin parah. Oleh sebab itu dibutuhakn sistem informasi yang dapat membantu wanita mendeteksi secara dini masalah kesehatan reproduksi yang dialami wanita salah satunya dengan sistem pakar. Tujuan Penelitian ini yaitu untuk membuat aplikasi Screening of Reproductive Health (SHE) dalam upaya peningkatan kesehatan Reproduksi Wanita. Metode penelitian menggunakan metode perancangan sistem pakar dengan melakukan pengkodean dan tabel keputusan, membuat pohon keputusan dan flowchart. melakukan tahapan pengumpulan data berupa diskusi domain permasalahan dengan pakar, studi literatur, diskusi pohon keputusan dengan para pakar dan uji coba kepada 30 responden. Hasil penelitian menunjukkan bahwa sistem pakar telah dibuat sesuai dengan rancangan dan telah menghasilkan solusi yang dibutuhkan dalam menscreening kesehatan reproduksi disertai saran dan rekomendasi dari hasil diagnosa terkait upaya pencegahan ataupun penanggulangan masalah kesehatan reproduksi yang diidap ataupun yang dilakukan pengisian pada aplikasi SHE.
\end{abstract}

\begin{abstract}
Anemia, vaginal discharge, menstrual disorders, dysmenorrhea are some of the health problems experienced by women both on a mild to severe scale. And some can be fatal to death. Based on WHO data, 33\% of problems in men are $12.3 \%$ and in men are $12.3 \%$. Furthermore, in women's reproductive health problems more than women will experience problems. Increasingly difficult, new women difficulties after getting worse. Therefore an information system is needed that can help women overcome previous health problems by one of them with an expert system. The purpose of this study was to create an application for Reproductive Health Screening (SHE) in an effort to improve women's reproductive health. The research method used the expert system design method by coding and decision tables, making decision trees and flowcharts. conducted data completion stages in the form of domain discussions with experts, literature studies, discussion of decision trees with experts and trials for 30 respondents. The results showed that the expert system had been made according to the design and had produced the solutions needed in screening.
\end{abstract}

\section{PENDAHULUAN}

Masalah kesehatan reproduksi mendudukan peringkat lebih tinggi dibanding kesehatan reproduksi laki-laki. Kesehatan reproduksi wanita menurut WHO telah mencapai $33 \%$ dari jumlah seluruh badan penyakit yang diderita para perempuan di dunia. Sedangkan kesehatan reproduksi laki-laki hanya mencapai 12,3 \% ( Rejeki dalam Hamidiyah, 2014).

Organ reproduksi wanita memiliki peran yang penting dalam hubungan seksual, produksi dan perkembangan sel telur, menstruasi, kehamilan hingga proses persalinan. Gangguan pada sistem 
reproduksi wanita dapat menyebabkan gangguan seksual hingga sulit untuk hamil. Beberapa masalah kesehatan reproduksi yang sering dialami oleh wanita diantaranya anemia, keputihan, gangguan siklus menstruasi, dismenorhea.

Hasil data Riskesdas tahun 2013, prevalensi anemia di Indonesia yaitu sebanyak 21,7\%, 18,4\% usia 15-24 tahun (Kemenkes RI, 2013). Berdasarkan hasil Survei Kesehatan Rumah Tangga (SKRT) tahun 2012 menunjukkan bahwa prevalensi anemia remaja putri usia 10-18 tahun sebanyak $57,1 \%$ dan $39,5 \%$ usia 19 45 tahun. Remaja putri me miliki risiko paling tinggi terkena anemia (Kemenkes RI, 2013). Hasil beberapa survey kepada siswa sekolah di Indonesia juga terbukti menunjukkan prevalensi anemia sebesar 36\%-43\% (Astuti \& Rosidi, 2014).

Berdasarkan laporan pengabdian kepada masyarakat yaitu general check up yang dilakukan Akademi Kebidanan Ibrahimy Tahun 2016 menunjukkan bahwa dari 121 santri yang melakukan pemeriksaan $\mathrm{Hb}$, sebanyak $52 \%$ mengalami anemia dengan kadar $\mathrm{Hb}$ kurang dari $12 \mathrm{~g} / \mathrm{dL}$. Dimana 5 dari santri yang mengalami anemia memiliki kadar $\mathrm{Hb} 5 \mathrm{~g} / \mathrm{dL}$.

Begitu juga dengan kasus keputihan hampir diderita oleh $75 \%$ wanita di dunia (Pribakti, 2010). Hasil survey penelitian pendahuluan Hamidiyah (2013) pada remaja santri putri Asrama Ma'had Aly Pondok Pesantren Salafiyah Syafi'iyah menunjukkan bahwa $75 \%$ dari 40 responden mengalami keputihan patologis. Hasil penelitian menujukkan 94\% dari 50 responden mengalami keputihan dengan $50 \%$ memiliki kebiasaan perilaku kurang baik dalam menjaga organ genital eksterna.

Gangguan siklus menstruasi juga banyak dikeluhkan oleh wanita pada umumnya. Baik siklus yang tidak teratur, siklus pendek maupun siklus panjang yang tidak wajar. Belum lagi masalah dismenorhea yang kadang dianggap sepele oleh sebagian wanita (Pribakti, 2010).

Tingginya prevalensi masingmasing masalah kesehatan reproduksi yang hampir semua wanita alami ironi dengan rendahnya pengatahuan para wanita dalam menyadari masalah kesehatan reproduksi yang dialami. Sehingga tidak jarang, baru dapat terdeteksi setelah keadaan memburuk. Padahal, masalah kesehatan reproduksi ini dapat dideteksi secara mandiri oleh para wanita sehingga dapat dilakukan upaya pencegahan dan penanggulangan sejak dini.

Berkembangnya

zaman memudahkan akses semua orang untuk mendapatkan informasi dari dunia maya seperti google, wikipedia, blog dan sebagainya, hanya saja kevalidan informasi yang membutuhkan filter ketat. Oleh karena itu dibutuhkan sebuah sistem informasi yang dapat membantu wanita untuk mendapatkan akses informasi yang valid langsung dari genggaman. Sehingga sistem pakar berbasis web merupakan salah satu solusi yang dibutuhkan dalam melakukan deteksi dini masalah kesehatan reproduksi wanita yang dapat diakses via dekstop ataupun handphone.

Tujuan penelitian ini adalah agar user dapat mendiagnosa penyakit dari gejala yang dipilih di dalam option sistem sehingga user bisa mendapatkan saran tindakan apa yang harus dilakukan sebagai upaya penanggulangan ataupun pencegahan berdasarkan saran yang 
ditampilkan pada sistem yang pada akhirnya menjadi upaya peningkatan kesehatan reproduksi wanita.

\section{TINJAUAN PUSTAKA}

\section{Kesehatan Reproduksi Wanita}

Menurut WHO, Kesehatan reproduksi adalah kesejahteraan fisik, mental dan sosial yang utuh bukan hanya bebas dari penyakit atau kecatatan, dalam segala aspek yang berhubungan dengan sistem reproduksi, fungsi serta prosesnya.

Masalah kesehatan reproduksi wanita dapat menyebabkan morbiditas dan mortalitas baik yang berkaitan dengan kehamilan. Di dalamnya juga termasuk masalah gizi dan anemia, penyebab dan komplikasi dari kehamilan, masalah kemandulan, gangguan siklus menstruasi, dismenorhea, keputihan dan ketidaksuburan.

\section{Anemia}

Anemia merupakan salah satu masalah kkesehatan reproduksi wanita yaitu suatu keadaan dimana komponen hemoglobin $(\mathrm{Hb})$ di dalam darah jumlahnya kurang dari kadar normal. Gejala yang sering timbul yaitu pusing, lemah, letih, lelah dan lesu. Kadang kala anemia tidak menimbulkan gejala yang jelas seperti mudah lelah bila berolahraga, sulit konsentrasi dan mudah lupa. Ironisnya adalah kebanyakan penderita tidak tahu serta tidak menyadari. Umumnya seseorang mulai curiga akan menderita anemia saat keadaan sudah parah, dimana gejalanya terlihat lebih jelas, seperti pucat, pusing, jantung berdebar-debar, mudah kehabisan napas ketika naik tangga atau olahraga.

Anemia pada remaja dapat menyebabkan dampak keterlambatan pertumbuhan fisik, gangguan perilaku, dan emosional. Anemia yang terjadi pada remaja putri juga merupakan risiko terjadinya gangguan fungsi fisik dan mental, serta dapat meningkatkan risiko terjadinya gangguan pada saat kehamilan nantinya. Bila keadaan akut, keadaan anemia dapat menyebabkan kematian. (Sediaoetomo dalam Hamidiyah, dkk , 2019).

\section{Keputihan}

Keputihan merupakan kondisi ketika lendir atau cairan yang keluar dari vagina. Keputihan merupakan cara alami tubuh untuk menjaga kebersihan dan kelembapan organ kewanitaan. Akan tetapi keputihan yang dialami setiap wanita berbeda-beda, mulai dari jumlah cairan yang keluar hingga warna dan tekstur cairan. Hal ini dapat mengindikasikan keputihan yang terjadi normal atau tidak normal. Keputihan tidak normal dapat disebabkan oleh infeksi, baik karena jamur, bakteri (Vaginosis Bakterialis, Gonore, Chlamydia), atau parasit (Trikomoniasis). Selain infeksi, keputihan juga dapat menjadi tanda dari kanker rahim atau leher rahim.

\section{Gangguan Menstruasi}

Gangguan menstruasi juga merupakan masalaha kesehatan reproduksi yang sering dialami wanita. Gangguan menstruasi bisa berupa perdarahan yang terlalu banyak atau terlalu sedikit, siklus menstruasi yang tidak teratur, menstruasi yang terjadi lebih dari 7 hari, tidak menstruasi lebih dari 3 bulan, atau bahkan tidak pernah haid sama sekali. Gangguan menstruasi juga bisa disertai dengan keluhan berat, seperti nyeri dan kram parah, hingga depresi menjelang menstruasi.

Dismenorhea 
Dismenorhea adalah gejala nyeri yang dirasakan semakin berat pada perut, migrain, atau mood swing. Pada umumnya dismenorhea terjadi dua hari pertama saat datang bulan. Dysmenorrhea disebabkan adanya kontraksi pada otot rahim yang kuat. Pada sebagian perempuan, rasa nyeri bisa sangat hebat, bisa pula amat ringan. Perempuan dengan dysmenorrhea yang hebat, kemungkinan besar memproduksi banyak prostaglandin di dalam rahimnya. Prostaglandin menyebabkan otot-otot rahim bergerak lebih kuat dan sering, sehingga menyebabkan turunnya aliran darah ke dalam rahim. Akibatnya syaraf-syaraf di rahim jadi lebih sensitif terhadap rasa nyeri.

\section{Sistem Pakar}

Sistem pakar adalah sistem yang berusaha mengadopsi pengetahuan Pakar ke dalam komputer, sehingga komputer dapat menyelesaikan permasalahan tersebut layaknya seorang pakar (Kusumadewi, 2003). Sampai saat ini telah banyak sistem pakar yang sudah ada.

Sistem pakar terbuat dari domain pengetahuan tertentu untuk suatu kepakaran tertentu mendekati kemampuan manusia pada salah satu bidang. Sistem pakar ditujukan untu menyelesaikn solusi yang memuaskan sebagaimana yang dilakukan oleh seorang pakar.

Terdapat beberapa pertimbangan penggunaan sistem pakar yaitu: a. Membantu melestarikan pengetahuan dan keahlian pakar. b. Keahlian merupakan hal langka, mahal dan atau tak terbatas. c. Dapat mudah digunakan walaupun bukan seorang ahli.

Arsitektur Sistem terdiri dari dua bagian utama yaitu lingkungan pengembang dan konsultasi (Turban, 2005). Mesin inferensi merupakan bagian yang terdiri dari mekanisme fungsi berfikir dan pola penalaran sistem yang digunakan oleh seorang pakar. Mekanisme ini ditujukan untuk menganalisa masalah tertentu yang pada selanjutnya akan mencari jawaban atau kesimpulan. Mesin inferensi terdiri dari tiga elemen pokok (Turban, 2005) yaitu : 1. Penerjemah (Interpreter), yaitu untuk menjalankan pilihan agenda dengan menerapkan pengetahuan yang ada. 2. Pengaturan (Scheduler), untuk mengatur kontrol dari agenda. Penalaran mempengaruhi inferensi jenis prioritas yang telah jelas atau kriteria lain dalam agenda. 3. Kemampuan Penyelesaian (Consistency Enforcer), untuk menjaga ketepatan representasi penyelesaian yang muncul. Bagian ini akan berusaha memelihara konsistensi dalam merepresentasikan solusi yang darurat. Mesin inferensi dimulai dengan pelacakan kemudian mencocokkan dalam pengetahuan dengan fakta yang ada dalam basis data.

Adapun teknik pelacakan (Kusumadewi, 2003) yaitu :

a) Forward Chaining. Teknik pelacakan forward chaining dapat dilihat pada Gambar 1.

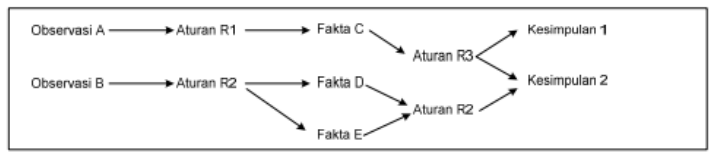

Gambar 1.

b) Backward Chaining

Teknik pelacakan forward chaining dapat dilihat pada Gambar 2.

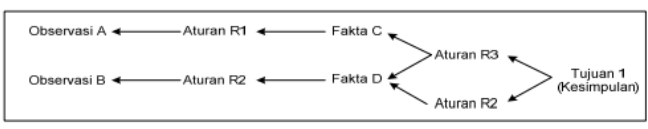

Gambar 2. 
Kedua metode inferensi tersebut dipengaruhi oleh tiga macam penelusuran, yaitu Depth-first search, Breadth-first search dan Best-first search.

\section{Representasi Pengetahuan}

Beberapa model dari representasi pengetahuan yaitu :

a. Representasi Logika Input yaitu merupakan proses logika yang juga disebut premise atau fakta, fakta digunakan dalam proses logika untuk membuat output yang juga merupakan kesimpulan atau disebut inferensi kesimpulan.

b. Jaringan Semantik (Semantic Networks) Representasi jaringan semantik yaitu gambaran grafis pengetahuan yang menunjukkan hubungan hirarki dari objek

c. Kaidah Produksi (Production Rules) Kaidah produksi yaitu representasi yang disusun atas kaidah yang mengikuti pola kondisi-aksi yaitu pasangan : “ IF Kondisi (Premise atau antecedent), THEN Aksi (hasil, atau kesimpulan, atau konsekuensi)".

d. Bingkai (Frames) merupakan struktur data yang memasukan seluruh pengetahuan tentang objek tertentu. Pengetahuan diatur dalam struktur hirarki khusus. setiap bingkai menggambarkan suatu objek.

e. Pohon Keputusan yaitu struktur berupa pohon yang menggambarkan secara hirarkis.

\section{METODE}

\section{Pengumpulan Data}

Tahapan pengumpulan data meliputi:

1. Diskusi domain permasalahan sistem reproduksi wanita

Diskusi dilakukan pada awal pertemuan dengan para pakar, sehingga mendapatkan penjelasan terkait dengan gejala, penyakit dan saran bagi penderita.

2. Studi Literatur

Studi literatur dilakukan bersumber dari text book, jurnal bereputasi sebagai bahan menyusun kerangka gejala, diagnosa dan saran rekomendasi

3. Diskusi pohon keputusan

Diskusi dilakukan bersama pakar dengan menggunakan draft pohon keputusan yang telah disusun berdasarkan hasil diskusi sebelumnya dan studi literatur

4. Uji Coba Sistem

Uji coba sistem atau trial and error sistem dilakukan kepada 30 responden dengan kriteria wanita dan memiliki lata belakang kesehatan. Uji coba dilakukan pengulangan apabila terdapat error, hingga error sistem tidak ditemukan.

\section{Representasi Pengetahuan}

Pengetahuan diperoleh dan digambarkan dalam bentuk format yang mudah dipahami dan bisa dieksekusi pada komputer. Tujuannya adalah untuk membuat struktur yang digunakan dalam pengkodean pengetahuan ke suatu program.

Terdapat beberapa cara untuk menggambarkan pengetahuan, diantaranya dengan aturan produksi, sehingga dapat ditangani oleh mesin inferensi sebagai "otak" sistem pakar. Langkah yang dapat dilakukan yaitu menyusun tabel keputusan dan pohon keputusan, mengkonversi pohon keputusan menjadi kaidah produksi yang digambarkan dalam bentuk flowchart.

Kode dan tabel keputusan dan gangguan sistem reproduksi wanita berdasarkan gejala sebagaimana pada

Tabel 1 dan 2.


Tabel 1. Kode

\begin{tabular}{|c|c|}
\hline $\begin{array}{l}\text { Kriteria } \\
\text { Kode }\end{array}$ & Kriteria \\
\hline K01 & Anemia \\
\hline K02 & Gangguan Menstruasi \\
\hline K03 & Keputihan \\
\hline K04 & Desminorhea \\
\hline K05 & BMI \\
\hline \multicolumn{2}{|l|}{ Penyakit } \\
\hline P01 & Indikasi Anemia \\
\hline P02 & Tidak ada indikasi anemia \\
\hline P03 & Sehat \\
\hline P04 & Amenore \\
\hline P05 & Polimenore \\
\hline P06 & Oligomenore \\
\hline P07 & Menoragia \\
\hline P08 & Normal \\
\hline P09 & Keputihan Fisiologis (normal) \\
\hline $\mathrm{P} 10$ & Keputihan Patologis (tidak normal) \\
\hline $\mathrm{P} 11$ & Dismenorehea \\
\hline $\mathrm{P} 12$ & Tidak dismenorhea \\
\hline $\mathrm{P} 13$ & Dismenorhea tingkat akut \\
\hline P14 & Sangat kurus \\
\hline P15 & Kurus \\
\hline P16 & Agak kurus \\
\hline P17 & BMI Normal \\
\hline P18 & Pra-obesitas \\
\hline P19 & Obesitas tingkat I \\
\hline $\mathrm{P} 20$ & Obesitas tingkat II \\
\hline P21 & Obesitas tingkat III \\
\hline \multicolumn{2}{|c|}{ Gejala Anemia } \\
\hline Kode & Gejala \\
\hline G01 & Lemah, letih, lesu, lunglai, lelah \\
\hline G02 & Konjungtiva (kelopak mata bagian dalam) mata pucat \\
\hline G03 & Ujung tangan pucat \\
\hline G04 & Bibir pucat \\
\hline \multicolumn{2}{|c|}{ Gejala Gangguan Menstruasi } \\
\hline Kode & Gejala \\
\hline G05 & Menstruasi setiap bulan selama tiga bulan terakhir \\
\hline G06 & Jumlah darah yang keluar lebih banyak dari biasanya \\
\hline G07 & Lama menstruasi anda lebih dari 8 hari \\
\hline G08 & Terkadang tekstur darah berupa bekuan darah \\
\hline G09 & Jumlah darah yang keluar selama menstruasi sangat banyak (butuh 5 atau lebih pembalut per hari) \\
\hline G10 & Selisih hari menstruasi selama tiga bulan terakhir kurang dari 21 hari \\
\hline G11 & Selisih hari menstruasi selama tiga bulan terakhir lebih dari 35 hari \\
\hline \multicolumn{2}{|c|}{ Gejala keputihan } \\
\hline Kode & Gejala \\
\hline G12 & Pernah mengalami keputihan \\
\hline G13 & Keputihan terjadi mendekati masa menstruasi atau 1 minggu setelah menstruasi \\
\hline G14 & Saat mengalami keputihan, merasa gatal di bagian organ genital \\
\hline G15 & Saat mengalami keputihan, merasa panas di bagian organ genital \\
\hline G16 & Jumlah cairan keputihan banyak (seperti menstruasi) \\
\hline G17 & Konsentrasi cairan keputihan kental seperti lendir \\
\hline G18 & Konsentrasi cairan keputihan menggumpal \\
\hline
\end{tabular}




$\begin{array}{ll}\text { G19 } & \text { Konsentrasi cairan keputihan cair tidak lengket } \\ \text { G20 } & \text { Karakteristik aroma keputihan bau amis/busuk } \\ \text { G21 } & \text { Karakteristik aroma keputihan tidak beraroma menyengat } \\ \text { G22 } & \text { Karakteristik warna keputihan bening } \\ \text { G23 } & \text { Karakteristik keputihan berwarna putih susu } \\ \text { G24 } & \text { Karakteristik keputihan berwarna kuning } \\ \text { G25 } & \text { Karakteristik keputihan berwarna kuning kehijauan } \\ \text { G26 } & \text { Karakteristik keputihan berwarna hijau }\end{array}$

\section{Gejala desminorhea}

Kode Gejala

G27 Nyeri di bagian perut bawah saat mendekati waktu menstruasi

G28 Nyeri di bagian perut bawah saat hari pertama hingga ketiga menstruasi

G29 Nyeri bagian perut bawah selama lebih dari 3 hari

G30 Jika skala tingkat nyeri bagian perut bawah dari tidak nyeri sampai nyeri sekali antara 1-10, skala nyeri lebih dari 7

G31 Nyeri perut bagian bawah saat menjelang menstruasi atau saat menstruasi menyebabkan tidak dapat

\section{Gejala BMI}

Kode Gejala

G32 BMI kurang dari 16.00

G33 BMI lebih dari 16.01 dan kurang dari 16.99

G34 BMI lebih dari 17.00 dan kurang dari 18.49

G35 BMI lebih dari 18.50 dan kurang dari 24.99

G36 BMI lebih dari 25.00 dan kurang dari 29.99

G37 BMI lebih dari 30.00 dan kurang dari 34.99

G38 BMI lebih dari 35.00 dan kurang dari 39.99

G39 BMI lebih dari 40.00 


\begin{tabular}{|c|c|c|c|c|c|c|c|c|c|c|c|c|c|c|c|c|c|c|c|c|c|}
\hline Kode & P01 & P02 & $\mathbf{P 0 3}$ & P04 & P05 & P06 & P07 & P08 & P09 & P10 & P11 & P12 & P13 & P14 & P15 & P16 & P17 & P18 & P19 & $\mathbf{P 2 0}$ & $\mathbf{P 2 1}$ \\
\hline G01 & $\sqrt{ }$ & $\sqrt{ }$ & & & & & & & & & & & & & & & & & & & \\
\hline G02 & $\sqrt{ }$ & & & & & & & & & & & & & & & & & & & & \\
\hline G03 & $\sqrt{ }$ & & & & & & & & & & & & & & & & & & & & \\
\hline G04 & $\sqrt{ }$ & & & & & & & & & & & & & & & & & & & & \\
\hline G05 & & & & $\sqrt{ }$ & $\sqrt{ }$ & $\sqrt{ }$ & & $\sqrt{ }$ & & & & & & & & & & & & & \\
\hline G06 & & & & & $\sqrt{ }$ & $\sqrt{ }$ & $\sqrt{ }$ & $\sqrt{ }$ & & & & & & & & & & & & & \\
\hline G07 & & & & & $\sqrt{ }$ & $\sqrt{ }$ & $\sqrt{ }$ & $\sqrt{ }$ & & & & & & & & & & & & & \\
\hline G08 & & & & & $\sqrt{ }$ & $\sqrt{ }$ & $\sqrt{ }$ & $\sqrt{ }$ & & & & & & & & & & & & & \\
\hline G09 & & & & & $\sqrt{ }$ & $\sqrt{ }$ & $\sqrt{ }$ & $\sqrt{ }$ & & & & & & & & & & & & & \\
\hline G10 & & & & & $\sqrt{ }$ & & & & & & & & & & & & & & & & \\
\hline G11 & & & & & & $\sqrt{ }$ & & & & & & & & & & & & & & & \\
\hline G12 & & & & & & & & & $\sqrt{ }$ & $\sqrt{ }$ & & & & & & & & & & & \\
\hline G13 & & & & & & & & & $\sqrt{ }$ & $\sqrt{ }$ & & & & & & & & & & & \\
\hline G14 & & & & & & & & & & $\sqrt{ }$ & & & & & & & & & & & \\
\hline G15 & & & & & & & & & & $\sqrt{ }$ & & & & & & & & & & & \\
\hline G16 & & & & & & & & & & $\sqrt{ }$ & & & & & & & & & & & \\
\hline G17 & & & & & & & & & $\sqrt{ }$ & $\sqrt{ }$ & & & & & & & & & & & \\
\hline G18 & & & & & & & & & & $\sqrt{ }$ & & & & & & & & & & & \\
\hline G19 & & & & & & & & & $\sqrt{ }$ & $\sqrt{ }$ & & & & & & & & & & & \\
\hline $\mathrm{G} 20$ & & & & & & & & & & $\sqrt{ }$ & & & & & & & & & & & \\
\hline G21 & & & & & & & & & $\sqrt{ }$ & $\sqrt{ }$ & & & & & & & & & & & \\
\hline G22 & & & & & & & & & $\sqrt{ }$ & $\sqrt{ }$ & & & & & & & & & & & \\
\hline G23 & & & & & & & & & & $\sqrt{ }$ & & & & & & & & & & & \\
\hline G24 & & & & & & & & & & $\sqrt{ }$ & & & & & & & & & & & \\
\hline G25 & & & & & & & & & & $\sqrt{ }$ & & & & & & & & & & & \\
\hline G26 & & & & & & & & & & $\sqrt{ }$ & & & & & & & & & & & \\
\hline G27 & & & & & & & & & & & $\sqrt{ }$ & & $\sqrt{ }$ & & & & & & & & \\
\hline G28 & & & & & & & & & & & $\sqrt{ }$ & & $\sqrt{ }$ & & & & & & & & \\
\hline G29 & & & & & & & & & & & $\sqrt{ }$ & & $\sqrt{ }$ & & & & & & & & \\
\hline G30 & & & & & & & & & & & & & $\sqrt{ }$ & & & & & & & & \\
\hline G31 & & & & & & & & & & & & & $\sqrt{ }$ & & & & & & & & \\
\hline G32 & & & & & & & & & & & & & & $\sqrt{ }$ & & & & & & & \\
\hline G33 & & & & & & & & & & & & & & & $\sqrt{ }$ & & & & & & \\
\hline G34 & & & & & & & & & & & & & & & & $\sqrt{ }$ & & & & & \\
\hline G35 & & & & & & & & & & & & & & & & & $\sqrt{ }$ & & & & \\
\hline G36 & & & & & & & & & & & & & & & & & & $\sqrt{ }$ & & & \\
\hline G37 & & & & & & & & & & & & & & & & & & & $\sqrt{ }$ & & \\
\hline G38 & & & & & & & & & & & & & & & & & & & & $\sqrt{ }$ & \\
\hline G39 & & & & & & & & & & & & & & & & & & & & & $\sqrt{ }$ \\
\hline G40 & & & & & & & & & & & & & & & & & & & & & \\
\hline
\end{tabular}

Author : Azizatul Hamidiyah, Muhasshanah | Publish : 28 Juli 2020| Vol.4,No.2,Tahun 2020| 127 
Pohon Keputusan

Pohon keputusan dibuat agar memudahkandalam mempresentasikan

pengetahuan ke dalam bahasa yang mudah dimengerti oleh mesin inferensi.

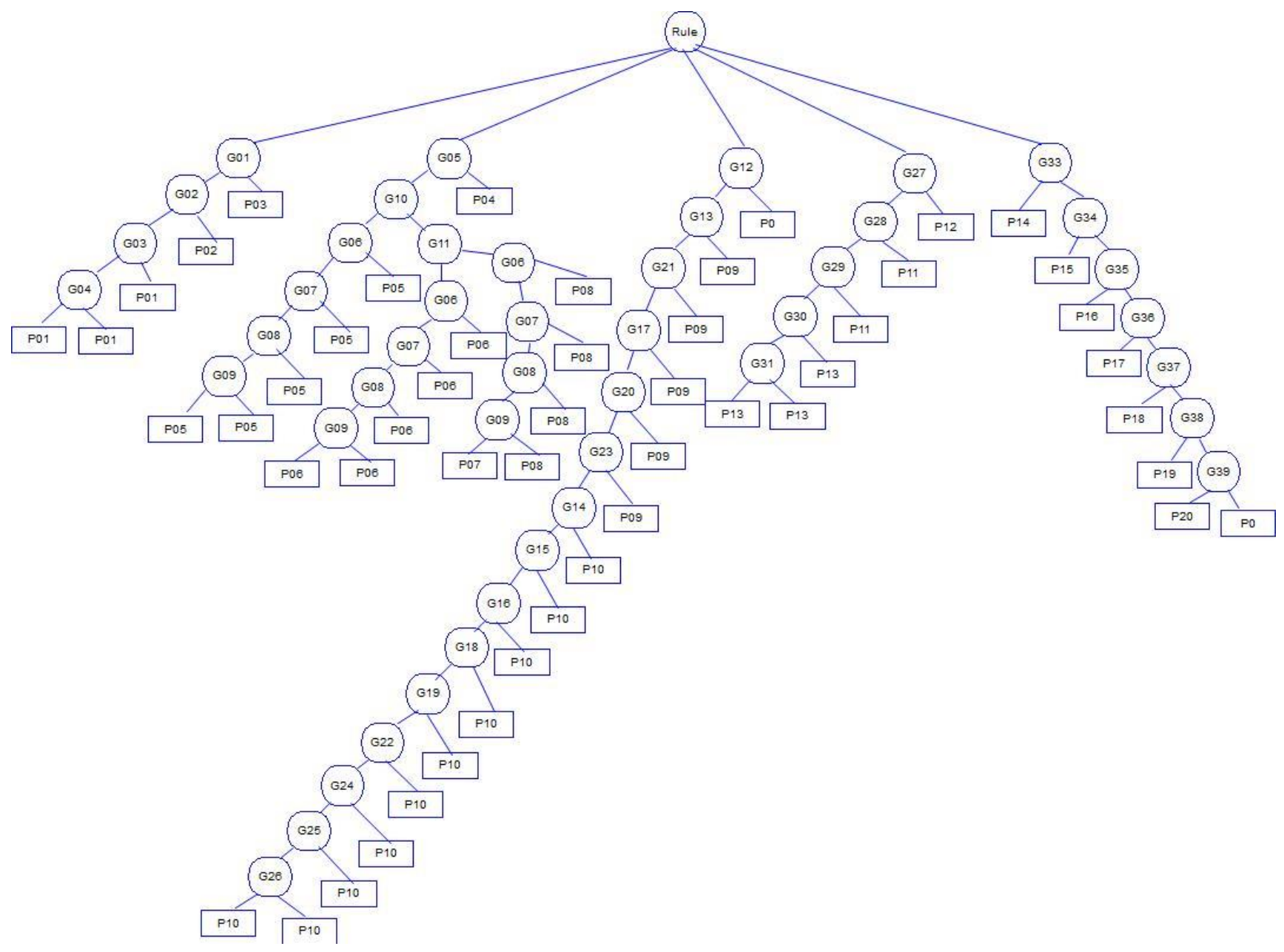

Gambar 3.Pohon Keputusan 


\section{Flowchart}

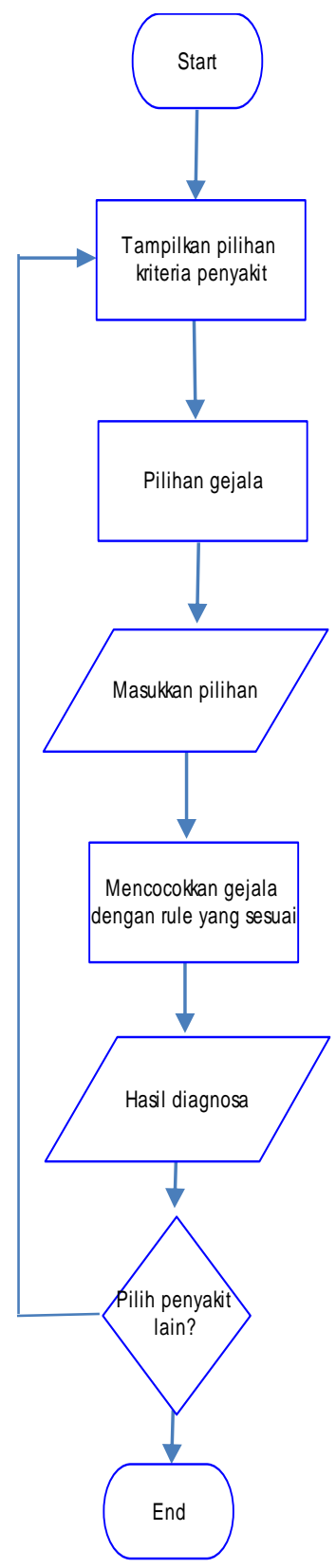

Gambar 4. Flowchart

\section{HASIL DAN PEMBAHASAN}

Screening of Reproductive Health (SHE) dirancang untuk mendiagnosa gangguan pada sistem reproduksi wanita terdiri dari beberapa form yang memiliki fungsi berbeda. Hanya form yang dipilih yang akan muncul.

Aplikasi SHE dapat diakses baik via web, baik via dekstop ataupun menggunakan telepon

dengan

link

http://she.fik.ibrahimy.ac.id/.

Sistem ini telah dilakukan uji coba atau trial and error kepada 30 responden yaitu wanita yang berlatar belakang seorang bidan atau tenaga kesehatan lainnya. Hasil pada uji coba menunjukkan bahwa sistem pakar SHE telah sesuai antara gejala yang dipilih dengan diagnosa serta saran yang direkomendasikan sebagai upaya pencegahan ataupun penanggulangan gangguan sistem reproduksi wanita yang sedang terganggu. pakar SHE.

Secara rinci berikut display sistem

\section{Halaman Depan}

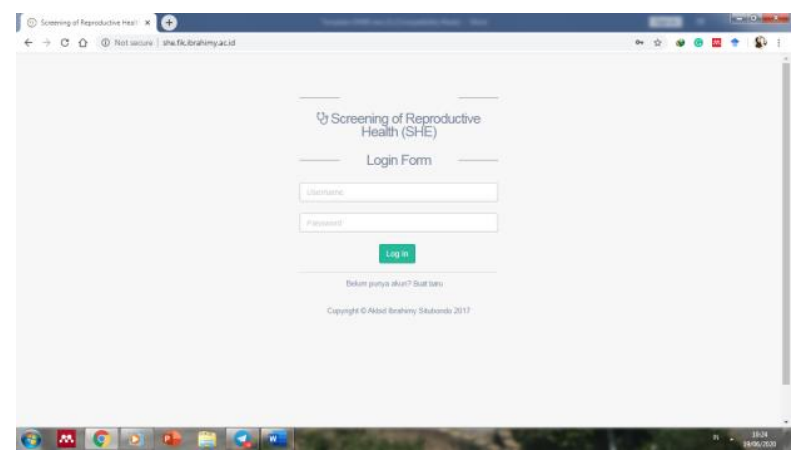

Gambar 5. Tampilan Halaman Depan

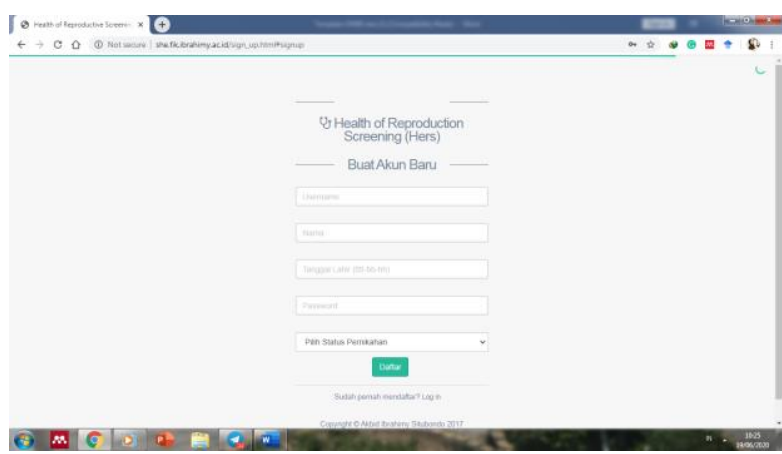

Gambar 6. Tampilan Registrasi

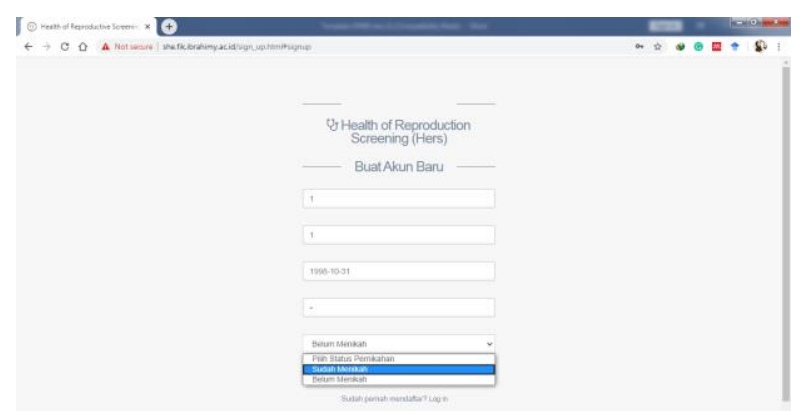


Gambar 7. Tampilan Opsi Registrasi

\section{Menu Menu Utama}
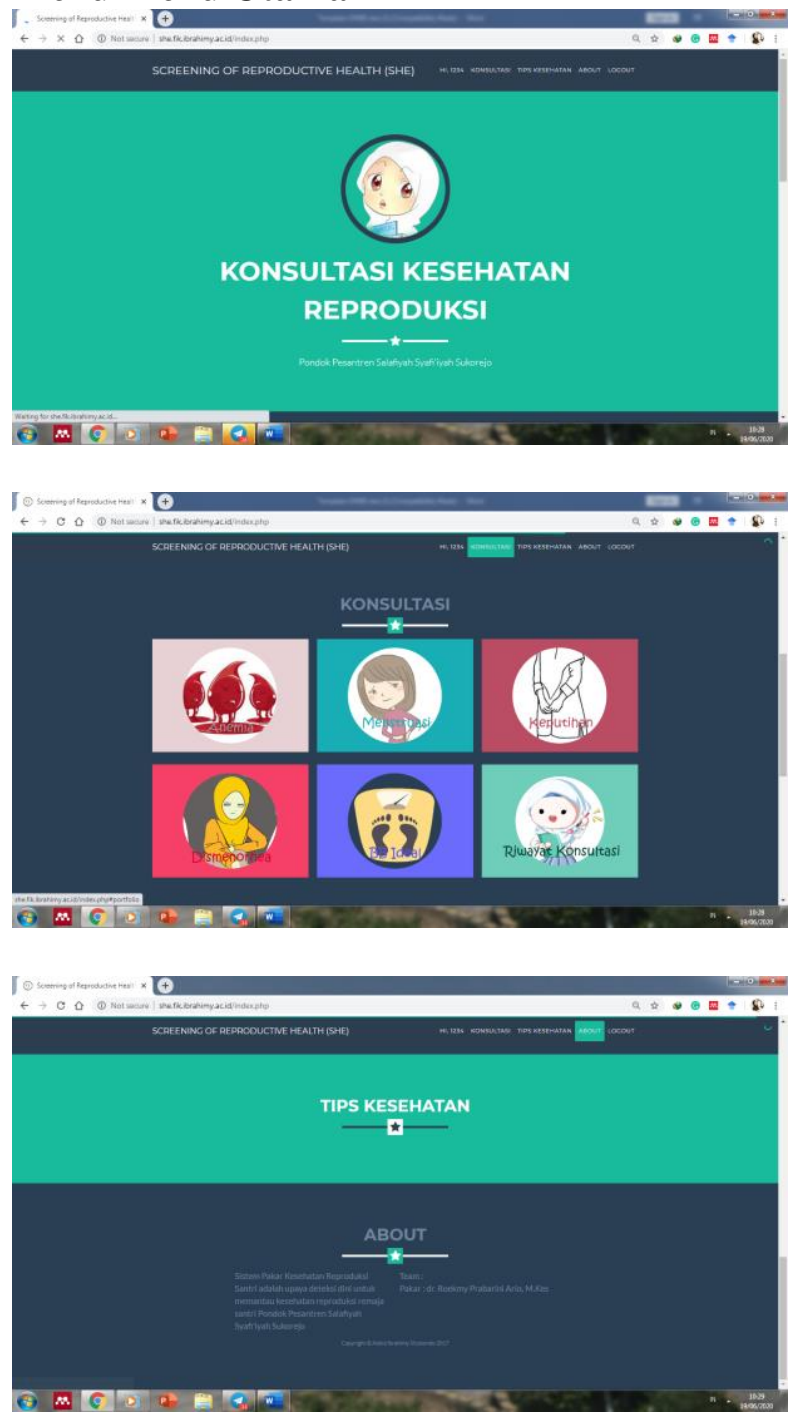

Gambar 8. Tampilan Menu Utama

Pada menu utama terdapat pilihan menu sistem pakar berupa deteksi anemia, gangguan sikluls menstruasi, keputihan, dismenorhea, Indeks Massa Tubuh (IMT) dan riwayat konsultasi sebelumnya. Dimana masing-masing menu ini akan meminta user untuk memilih gejala yang dialami untuk didiagnosa.

\section{Menu Input Gejala}

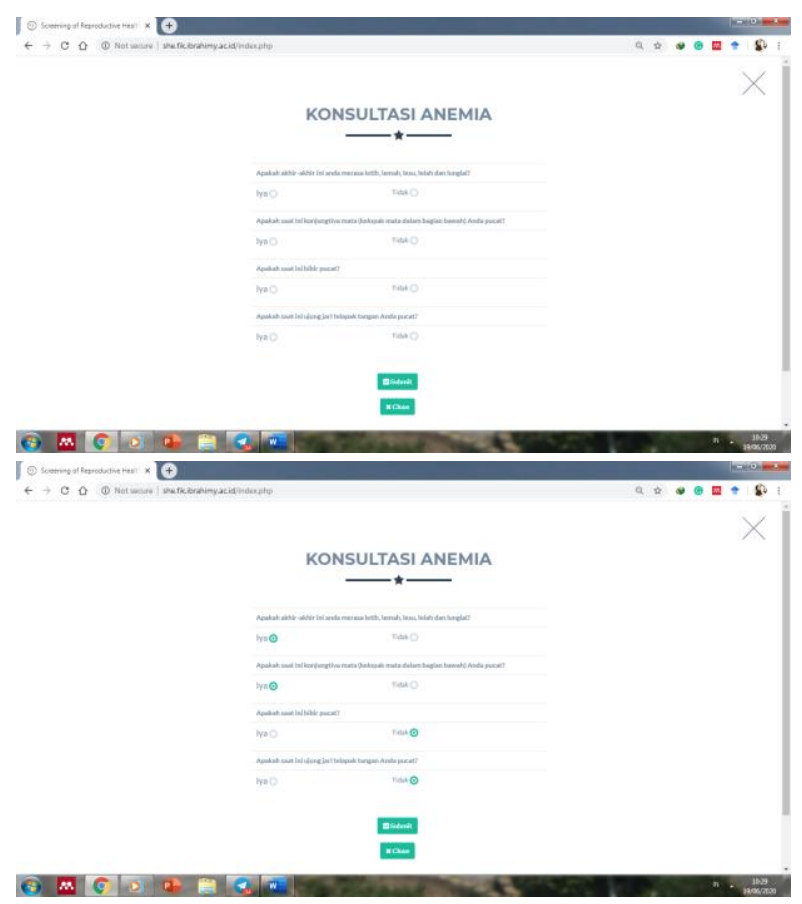

Gambar 9. Tampilan Menu Input Gejala Anemia

\section{Menu Diagnosa}

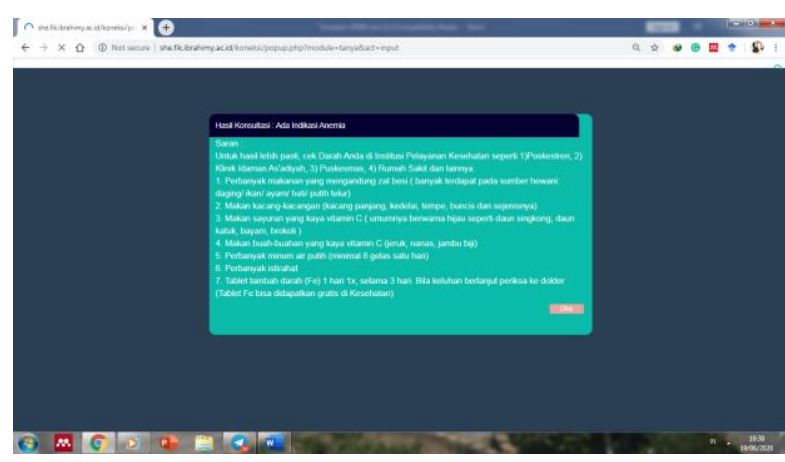

Gambar 10. Tampilan Menu Diagnosa

Tampilan menu diagnosa juga disertai dengan saran dan rekomendasi upaya pencegahan dan atau penanggulangan.

\section{KESIMPULAN}

Pembuatan sistem pakar SHE dalam mendiagnosa gangguan sistem reproduksi wanita telah sesuai dengan rancangan. Sistem pakar SHE telah memberikan solusi yang dibutuhkan sesuai gejala yang dipilih user. Basis pengetahuan digambarkan berdasarkan nama gangguan atau penyakit, gejala dan saran 
rekomendasi. Aplikasi SHE juga dapat digunakan untuk sebagai upaya screening gangguan pada sistem reproduksi wanita disertai saran penanggulangan dan pencegahan sehingga para wanita dapat mendiagnosa secara dini dan mandiri sehingga meminimalisir keadaan semakin buruk.

\section{DAFTAR PUSTAKA}

Hamidiyah, A. dkk. 2014. Perilaku Santri Menjaga Kesehatan Organ Genital Eksterna dengan Kejadian Keputihan. Oksitosin: Jurnal Ilmiah Kebidanan. $1(1)$. P.35-39.

https://journal.ibrahimy.ac.id/index.php loksitosin/article/view/405/392

Hamidiyah, A. dkk. 2019. Faktor Determinan Anemia Santri Putri. Oksitosin: Jurnal Ilmiah Kebidanan. 6(1). P.64-72. https://journal.ibrahimy.ac.id/index.php loksitosin/article/view/345/334

Kemenkes RI, 2013. Laporan Hasil Riset Kesehatan Dasar 2013. Jakarta: Litbang Kemenkes RI.

Kemenkes RI, 2013. Profil Kesehatan Indonesia. Jakarta: Pusat Data dan Informasi Kemenkes RI

Lynch, S., 2000. The Potential Impact of Iron Suplementation During. Am. J. Clin. Nutr, Volume 130, p. 488S.

Perwira, R.I., Aziz, A. 2013. Sistem Pakar Untuk Mendiagnosa Penyakit TBC Paru. Telematika. 9(2). P.63-74. file:///C:/Users/User/Downloads/285900-1-PB.pdf

Pribakti. 2010. Tips \& Trik Merawat Organ Intim. Yogyakarta: Pustaka Banua

Rejeki, Medika,S. 2008. Pfizer Woman Care (PWC) Ajak Perempuan Indonesia Waspadaic Gangguan

Sediaoetomo, A., 1992. Ilmu Gizi untuk Mahasiswa dan Profesi. I ed. Jakarta: Dian Rakyat.

Supariasa, 2002. Penilaian Status Gizi. Jakarta: EGC.
Turban, E., 2005, Decision Support System and Expert System, Prantice Hall International Inc, New Jersey.

Yip, R., 1998. The Challenge of Improving Iron Nutrition. European Journal of Clinical Nutrition. 